\title{
PENINGKATAN HASIL BELAJAR SISWA SMK PADA MATERI REAKSI REDOKS MENGGUNAKAN MODEL PEMBELAJARAN KOOPERATIF TIPE STUDENT TEAM ACHIEVEMENT DIVISION (STAD) DI KELAS X TEI-C SMKN 1 CIMAHI
}

\author{
Diah Marliana \\ SMKN 1 Cimahi, Cimahi Selatan, Kota Cimahi, Jawa Barat \\ diahm1643@gmail.com
}

\begin{abstract}
This study aims to improve student learning outcomes at Cimahi 1 State Vocational School Using the cooperative learning model type Student Team Achievement Division (STAD). The research method in this research is classroom action research (CAR) which consists of two cycles. The research subjects were 37 students of class $\mathrm{X}$ TEC-C SMKN 1 Cimahi on redox reaction material. The results of this study indicate the ability of students of class X TEI-C SMK 1 Cimahi can be improved through STAD support. This can be seen from the results of the initial test cycle II obtained a minimum value of 75 increased by $22.0 \%$ with an average value of 70.1 and from cycle II to cycle II increased by $15.9 \%$ with an average value of 75.4 . Then it can be saud that in cycle II the learning scenario has been said ti be successful.
\end{abstract}

Keywords: cooperative learning Redox reaction learning, STAD

\begin{abstract}
Abstrak
Penelitian ini bertujuan untuk meningkatkan hasil belajar siswa SMKN 1 Cimahi Menggunakan model pembelajaran kooperatif tipe Student Team Achievement Division (STAD). Metode penelitian dalam penelitian ini adalah penelitian tindakan kelas (PTK) yang terdiri dari dua siklus. Subjek penelitiannya adalah siswa kelas X TEC-C SMKN 1 Cimahi sebanyak 37 siswa pada materi reaksi redoks. Hasil dari penelitian ini menunjukan bahwa kemampuan siswa kelas X TEI-C SMKN 1 Cimahi dapat ditingkatkan melalui pendekatan STAD. Hal ini dapat dilihat dari hasil tes awal ke tindakan siklus I yang memperoleh nilai minimal 75 meningkat 22,0\% dengan nilai rata-rata 70,1 dan dari tindakan siklus I ke tindakan siklus II meningkat 15,9\% dengan nilai ratarata 75,4 sehingga dapat dikatakan bahwa pada siklus II skenario pembelajaran sudah dikatan berhasil.
\end{abstract}

Kata kunci: pembelajaran koperatif learning reaksi Redoks, STAD.

\section{PENDAHULUAN}

Pendidikan merupakan proses interaksi antara pendidik dan peserta didik baik secara formal, nonformal maupun informal, dimana ilmu yang didapat nantinya dapat diaplikasikan dalam kehidupan sehari-hari (Chotimah, et., al., 2019; Bernard, 2015:198; Islamiah, et. al, 2018:47; Siswanto, et. al, 2018:66). Visi pendidikan nasional adalah terwujudnya sistem pendidikan sebagai pranata sosial yang kuat dan berwibawa untuk memberdayakan semua warga negara Indonesia berkembang menjadi manusia yang berkualitas sehingga mampu dan proaktif menjawab tantangan jaman yang selalu berubah. Pemerintah menetapkan serangkaian prinsip penyelenggaraan sebagai proses pembudayaan dan pemberdayaan siswa yang berlangsung sepanjang hayat, dalam prosesnya diperlukan guru yang memberikan keteladanan, membangun kemauan, mengembangkan potensi dan kreatifitas siswa. Implikasi prinsip ini adalah pergeseran paradigma proses pendidikan, yaitu dari paradigma pengajaran ke paradigma pembelajaran (Depdiknas, 2008a: 5).

Sebagai pekerja profesional, guru harus memfasilitasi dirinya dengan seperangkat pengalaman, keterampilan, dan pengetahuan tentang keguruan (Bernard, 2015). Selain harus menguasai substansi keilmuan, guru juga harus menguasai model-model pembelajaran yang dapat melibatkan siswa secara 
aktif. Kimia merupakan ilmu yang mempelajari materi, perubahan materi, dan energi yang menyertai perubahan tersebut. Banyak konsep-konsep kimia yang tidak dapat dipahami siswa hanya dengan ceramah dan tulisan saja. Pada materi reaksi redoks, jika siswa hanya diwajibkan menghapal konsepkonsep yang abstrak saja tanpa diberikan visualisasi yang tepat, maka siswa akan mudah melupakan konsep tersebut (Fajriyah, 2019). Akibatnya banyak siswa yang tidak dapat memahami konsep-konsep kimia secara jelas, bahkan sering terjadi miskonsepsi atau sulit dipahami di antara siswa dalam satu kelas terhadap satu permasalahan yang sama.

Salah satu mata pelajaran ya ng penting untuk dipelajari adalah matapelajaran kimia untuk siswa di tingkat sekolah menengah atas, yang mana salah satu tujuan mempelajari kimia adalah untuk untuk melatih kemampuan berfikir logis, kritis, cermat dan tepat serta membekali siswa untuk dapat mempelajari ilmu pengetahuan dan teknologi pada jenjang sekolah lanjutannya, karena ilmu kimia merupakan dasar bagi ilmu-ilmu pengetahuan yang lain seperti, kedokteran, farmasi, teknik, geologi dan banyak lagi.

Kenyataan dilapangan menunjukan bahwa kimia merupakan salah satu mata pelajaran yang sulit bagi siswa khususnya siswa SMK, yang mana banyak dari hasil belajar siswa pada mata pelajaran kimia terbilang rendah, Hal ini juga dialami oleh siswa di SMKN 1 Cimahi dimana nilai kimia umumnya relatif rendah sehingga diperlukan inovasi dan strategi pembelajaran dari guru untuk membantu siswa memahami materi dalam mata pelajaran kimia serta sesuai dengan karakteristik siswa.

Model pembelajaran yang akan dikembangkan dalam penelitian ini adalah model pembelajaran kooperatif tipe Student Team Achievement Division (STAD), model pembelajaran STAD adalah model pembelajaran kooperatif yang menekankan pada adanya aktifitas dan in teraksi diantara siswa agarsaling membantu dalam menguasai materi yang diajarkan, yang mana kegiatan belajar mengajar dengan meode ini berpusat pada siswa (Perdana et. al., 2014; Hidayati, 20)

diharapkan model ini dapat menjawab permasalahan yang ada, dapat meningkatkan motivasi belajar, rasa ingin tahu, jujur, sikap komunikatif, dan tanggungjawab siswa, sehingga menambah kecintaan terhadap kimia yang pada akhirnya dapat meningkatkan hasil belajar siswa. Berdasarkan uraian di atas, penyusun tertarik untuk melakukan penelitian dengan judul "Meningkatkan Hasil Belajar Siswa SMK pada Materi Reaksi Redoks Menggunakan Model Pembelajaran Kooperatif Tipe Student Team Achievement Division (STAD) di Kelas X TEI-C SMKN 1 Cimahi”

\section{METODE}

Subyek Penelitian tindakan kelas adalah siswa kelas X TEI-C SMKN 1 Cimahi Kota Cimahi, yang berjumlah 37 siswa yang terdiri dari 23. siswa laki-laki dan 14 siswa perempuan. Mata pelajaran yang menjadi sasaran penelitian adalah Kimia kls X khususnya pada materi Reaksi Redoks.

\section{Faktor yang Diselidiki}

Untuk menjawab permasalahan dalam penelitian ini, ada beberapa faktor yang perlu diselidiki. Faktor-faktor tersebut adalah 
a. Faktor metoda yaitu dengan memperhatikan bagaimana persiapan materi pelajaran dengan menerapakan pendekatan STAD

b. Faktor siswa yaitu memperhatikan apakah pemahaman reaksi redoks tergolong rendah, sedang, atau tinggi.

\section{Metode Penelitian}

Metode yang digunakan adalah penelitian tindakan kelas (PTK)

Penelitian tindakan kelas ini terdiri dari 2 siklus.

Adapun gambaran rencana pelaksanaan setiap siklus adalah sebagai berikut.

\section{Perencanaan (planning)}

Kegiatan dalam tahap perencanaan ini meliputi hal-hal sebagai berikut.

1. Studi pendahuluan terhadap prestasi belajar siswa.

2. Merencanakan pembelajaran dengan membuat Silabus, RPP.

3. Membuat soal tes akhir siklus.

4. Membuat lembar pengamatan aktivitas belajar pada pelajran Kimia.

5. Peneliti dan teman sejawat membuat lembar pengamatan pengelolaan pembelajaran Kimia dengan metode STAD

6. Merencanakan pembentukan kelompok heterogen.

\section{Pelaksanaan/implementasi tindakan (acting)}

Tahap pelaksanaan/implementasi tindakan merupakan tahap pelaksanan proses pembelajaran di kelas pada tahap tindakan, peneliti melakukan kegiatan pembelajaran seperti yang telah direncanakan yaitu kegiatan pembelajaran dengan menerapkan pendekatan proses. Pelaksanaan tindakan dilaksanakan dalam 2 kali pertemuan selama empat jam pelajaran (4x45 menit). Pertemuan pertama dimanfaatkan untuk proses pembelajaran berupa diskusi penemuan konsep dan proses diskusi menyelesaikan masalah dan presentasi kelompok. Sebelum pembelajaran ditutup guru memberikan reward kepada kelompok unggulan dengan skor 75 perkembangan tertinggi. Sedangkan pertemuan kedua digunakan untuk mengambil data tes akhisiklus. Dengan kata lain, penelitian ini dilaksanakan dalam dua siklus, sebagai berikut:

Siklus I

1) Perencanaan

2) Tindakan dan Observasi I pada siklus I pertemuan I

3) Refleksi I terhadap siklus I pertemuan I

4) Evaluasi I berdasarkan siklus I pertemuan I

5) Tindakan dan Observasi II pada siklus I pertemuan I

6) Refleksi II terhadap siklus I pertemuan II

7) Evaluasi II berdasarkan siklus I Pertemuan II

Siklus II

1) Perencanaan 
2)Tindakan dan Observasi I pada siklus II pertemuan I

3) Refleksi I terhadap siklus II pertemuan I

4) Evaluasi berdasarkan siklus II pertemuan I

5) Tindakan dan Observasi II pada siklus II pertemuan II

6) Refleksi II terhadap siklus II pertemuan II

7) Evaluasi II berdasarkan siklus II Pertemuan II

\section{Pengamatan (Observasi)}

Observasi dilakukan oleh teman sejawat. Lembar pengamatan digunakan untuk mengamati dan mengukur aktivitas belajar siswa serta aktivitas penelitian pada saat proses pembelajaran berlangsung. Langkah selanjutnya adalah mengumpulkan data prestasi belajar Kimia 37 siswa berdasarkan hasil tes akhir siklus dan pelaksanaan tugas yang diberikan oleh peneliti.

\section{Refleksi}

Refleksi merupakan analisis hasil observasi dan hasil tes. Refleksi dilaksanakan segera setelahtahap implementasi/tindakan dan observasi selesai. Pada tahap ini peneliti dan teman sejawat mendiskusikan hasil yang meliputi kelebihan dan kekurangan pada pembelajaran. Hasil refleksi ini akan digunakan sebagai perbaikan dalam pelaksanaan siklus berikutnya.

\section{HASIL}

Untuk menentukan tercapainya tujuan pendidikan dan pembelajaran perlu dilakukan usaha atau tindakan penilaian yang disebut juga dengan evaluasi. Untuk mengetahui hasil belajar pada penelitian ini dengan menerapkan model pembelajaran STAD, apakah terdapat peningkatan atau tidak dilihat dari kemampuan siswa dalam mengerjakan tugas kelompok, tugas individu, dan ulangan harian setiap siklus. Apabila terdapat peningkatan dari siklus I sampai siklus II, maka dikatakan hasil belajar siswa meningkat. Hasil tugas kelompok, tugas individu dan ulangan harian dianalisis dengan menggunakan analisis ketercapaian hasil belajar. Hasil belajar ini berdasarkan KKM dan kriteria belajar siswa yang ada di SMK NEGERI 1 Cimahi. Setelah dianalisis, maka diperoleh gambaran hasil tugas kelompok, hasil tugas individu, hasil ulangan harian dan hasil belajar siswa sebagai berikut :

\section{Tabel 1.}

Aktivitas Siswa Pada Pembelajaran

\begin{tabular}{|c|c|c|}
\hline No & Tindakan & Rata-rata \\
\hline 1 & Siklus I & 2,66 \\
2 & Siklus II & 3,22 \\
\hline
\end{tabular}




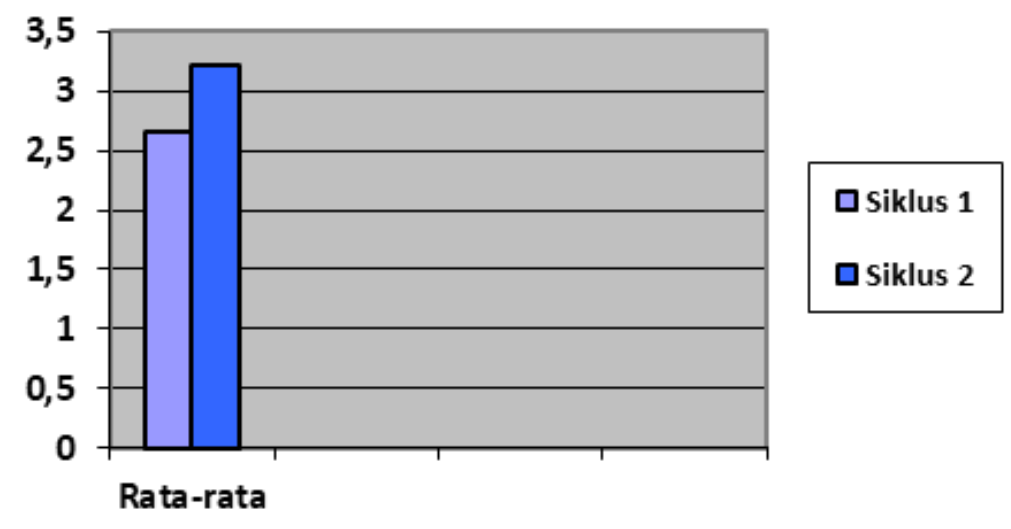

Gambar 1. Rata-rata aktivitas siswa

Setiap aktivitas siswa pada tiap siklus diberi skor rata-rata pengamatan dari tiga observer. Rata-rata skor pengamatan aktivitas siswa pada saat pembelajaran dapat dilihat pada tabel di bawah ini, berdasarkan tabel di bawah ini diperoleh bahwa aktivitas siswa mengalami perubahan yang positif dari setiap siklusnya, rata-rata skor pengamatan sktivitas siswa untuk tiap siklus dapat dilihat pada tabel berikut:

\section{Tabel 2}

Rata-rata Hasil Belajar

\begin{tabular}{|c|c|c|c|}
\hline No & Tindakan & Nilai $>75$ & Rata-rata \\
\hline 1 & Tes Awal & $40,5 \%$ & 57,90 \\
2 & Siklus I & $62,5 \%$ & 70,10 \\
3 & Siklus II & $78,4 \%$ & 75,41 \\
\hline
\end{tabular}

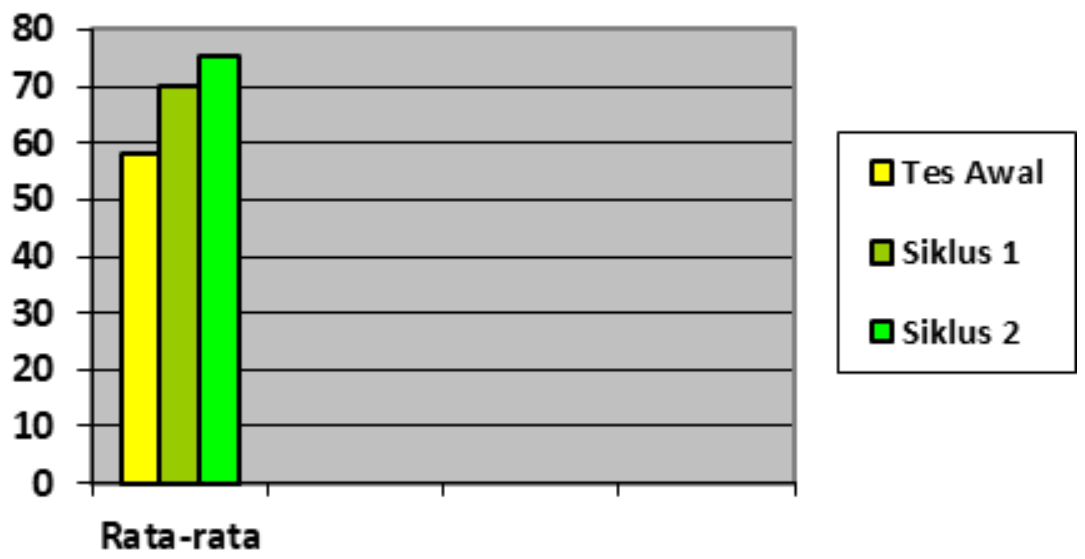

Gambar 2. Rata-rata hasil belajar

Berdasarkan tabel 2 terlihat bahwa hasil belajar siswa mengalami peningkatan, siswa yang nilainya lebih dari 75 dari siklus I ke siklus II naik sebesar 15,9\%. Begitu pula hasil belajar rata-rata siswa terdapat peningkatan sebesar 5,31.

Secara umum hasil belajar dengan menggunakan model pembelajaran kooperatif tipe STAD dapat meningkatkan hasil belajar Kimia siswa. Hal ini dapat dilihat dari tabel nilai akhir siswa dari hasil belajar sebelum dan sesudah menggunakan model pembelajaran kooperatif tipe STAD. 


\section{Tabel 3}

Analisis Respon Siswa

\begin{tabular}{|c|c|c|c|c|}
\hline Indikator & No. Item & $\begin{array}{l}\text { Skor Rata- } \\
\text { Rata Tiap } \\
\text { Item }\end{array}$ & $\begin{array}{l}\text { Skor Rata- } \\
\text { Rata Tiap } \\
\text { Indikator }\end{array}$ & $\begin{array}{l}\text { Skor Rata-rata } \\
\text { Respon Siswa }\end{array}$ \\
\hline \multirow{10}{*}{$\begin{array}{l}\text { Respon } \\
\text { Terhadap } \\
\text { Diskusi } \\
\text { Kelompok }\end{array}$} & 4 & 3.4 & \multirow{19}{*}{3,91} & \multirow{19}{*}{38,75} \\
\hline & 5 & 4,2 & & \\
\hline & 6 & 4,0 & & \\
\hline & 7 & 4,2 & & \\
\hline & 9 & 3,5 & & \\
\hline & 10 & 3,6 & & \\
\hline & 11 & 4,5 & & \\
\hline & 14 & 4,1 & & \\
\hline & 15 & 4,2 & & \\
\hline & 16 & 3,4 & & \\
\hline \multirow{9}{*}{$\begin{array}{c}\text { Respon } \\
\text { Terhadap } \\
\text { Pembelajaran }\end{array}$} & 1 & 4,0 & & \\
\hline & 2 & 3,8 & & \\
\hline & 3 & 4,2 & & \\
\hline & 8 & 4,4 & & \\
\hline & 12 & 4,6 & & \\
\hline & 13 & 4,4 & & \\
\hline & 17 & 3,6 & & \\
\hline & 18 & 4,6 & & \\
\hline & 20 & 4,8 & & \\
\hline
\end{tabular}

Berdasarkan hasil evaluasi pada tindakan siklus I dan siklus II terlihat peningkatan kemampuan siswa dalam menyelesaikan soal soal reaksi redoks itu artinya siswa lebih mudah memahami penjelasan secara team dalam suatu kelompok, karena indikator keberhasilan dalam penelitian telah tercapai, dalam hal ini minimal 78,4 \% siswa telah mencapai nilai > 75, maka penelitian ini dihentikan di siklus II. Ini berarti bahwa hipotesis tidakan telah tercapai yaitu melalui model pembelajaran kooperatif tipe STAD.

Berdasarkan hal di atas, dapat dikatakan bahwa penerapan pendekatan STAD pada kelas X TEI-C SMKN 1 Cimahi memberi dampak yang sangat baik terhadap hasil belajar dan kemampuan siswa dalam menyelesaikan soal-soal reaksi redoks. Hal ini sejalan dengan penelitian (Wahyuni, \& Widodo, 2018) yang menyatakan bahwa pembelajaran kooperatif STAD lebih dapat meningkatkan hasil belajar dan aktivitas siswa dibanding pembelajaran biasa pada materi reaksi redoks.

\section{KESIMPULAN}

Berdasarkan hasil observasi dan evaluasi pada setiap tindakan siklus dari penelitian ini maka dapat disimpulkan bahawa kemampuan siswa kelas X TEI-C SMKN 1 Cimahi dapat ditingkatkan melalui pendekatan STAD. Hal ini dapat dilihat dari hasil tes awal ke tindakan siklus I yang memperoleh nilai minimal 75 meningkat 22,0\% dengan nilai rata-rata 70,1 dan dari tindakan siklus I ke tindakan siklus II meningkat 15,9\% dengan nilai rata-rata 75,4 ( tabel 4.5) sehingga dapat dikatakan bahwa pada siklus II skenario pembelajaran sudah dikatan berhasil. Dimana penerapan pendekatan STAD pada kelas X 
TEI-C SMKN 1 Cimahi memberi dampak yang sangat baik terhadap hasil belajar dan kemampuan siswa dalam menyelesaikan soal-soal reaksi redoks.

\section{DAFTAR PUSTAKA}

Azizah, N. (2016). Pengembangan Lks Dan Penerapannya Dalam Pembelajaran Kooperatif Tipe STAD Untuk Meningkatkan Aktivitas dan Hasil Belajar Kimia Siswa. Jurnal Pijar Mipa, 11(1).

Arikunto, S. et. al. (2006). Penelitian Tindakan Kelas. Jakarta : Bumi Aksara.

Bernard, M. (2015). Meningkatkan kemampuan komunikasi dan penalaran serta disposisi matematik siswa SMK dengan pendekatan kontekstual melalui game adobe flash cs 4.0. Infinity Journal, 4(2), 197-222.

Chotimah, S., Ramdhani, F. A., Bernard, M., \& Akbar, P. (2019). Pengaruh Pendekatan Model-Eliciting Activities Terhadap Kemampuan Berpikir Kritis Matematik Siswa Smp Negeri Di Kota Cimahi. Journal on Education, 1(2), 68-77.

Depdiknas. (2006). Panduan Pengembangan Silabus Mata Pelajaran Matematika. Jakarta : Ditjen Manajemen Pendidikan Daar dan Menengah.

Fajriyah, L., Nugraha, Y., Akbar, P., \& Bernard, M. (2019). Pengaruh Kemandirian Belajar Siswa SMP Terhadap Kemampuan Penalaran Matematis. Journal on Education, 1(2), 288-296.

Hidayati, I. N. A., Redjeki, T., \& Hastuti, B. (2013). Penerapan model pembelajaran kooperatif tipe Student Team Achievement Division (STAD) untuk meningkatkan aktivitas dan prestasi belajar kimia pada materi pokok kesetimbangan kimia siswa kelas XI MAN Klaten tahun pelajaran 2011/2012. Jurnal Pendidikan Kimia, 2(2), 92-99.

Islamiah, N., Purwaningsih, W. E., Akbar, P., \& Bernard, M. (2018). Analisis Hubungan Kemampuan Pemecahan Masalah Matematis dan Self Confidence Siswa SMP. Journal on Education, 1(1), 47-57.

Perdana, D. D., Utomo, S. B., \& Yamtinah, S. (2014). Upaya Peningkatan Minat Dan Prestasi Belajar Materi Hidrokarbon Melalui Penerapan Model Pembelajaran Kooperatif Tipe Student Team Achievement Division (Stad) Berbantuan Kartu Soal Pada Siswa Kelas X Semester Genap SMA N 8 Surakarta. Jurnal Pendidikan Kimia, 3(1), 74-79.

Siswanto, R. D., Dadan, D., Akbar, P., \& Bernard, M. (2018). Penerapan Model Pembelajaran Kooperatif Tipe Auditorial, Intelectually, Repetition (Air) Untuk Meningkatkan Pemecahan Masalah Siswa Smk Kelas XI. Journal on Education, 1(1), 66-74.

Wahyuni, T., \& Widodo, W. (2018). Penggunaan lks dan model pembelajaran kooperatif stad untuk meningkatkan hasil belajar dan aktivitas belajar siswa kelas XII kimia analisis 1 SMKN 1 cerme gresik pada materi reaksi redoks dan sel volta. Jurnal penelitian pendidikan matematika dan sains, 1(2). 